\title{
Factors affecting mass transfer of protease in pelt during enzymatic bating process
}

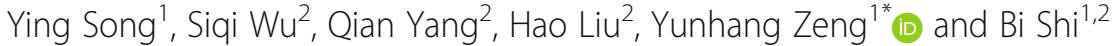

\begin{abstract}
Bating pelt with protease is an important process, which removes unwanted non-collagenous proteins from the pelt and moderately disperse hide collagen network. However, the grain surface, may be excessively hydrolyzed during bating due to the longer retention time of protease in the grain than in the middle layer caused by the low mass transfer rate of protease in pelt. Here, the effects of protease dosage, common auxiliaries and molecular weight of protease on protease transfer during bating were investigated so that we can find the key points to avoid excessive collagen damage, particularly in the grain. Observably, increasing protease dosage led to faster protease transfer and softer leather, but along with more considerable grain damage. Using penetrating agent JFC (fatty alcohol-polyoxyethylene ether) and ammonium sulfate enhanced protease transfer and simultaneously alleviated collagen damage due to the decrease in interfacial tension and electrostatic attraction between protease and pelt, respectively. Additionally, proteases with lower molecular weight transferred faster in pelt, which suggests that a potential strategy to solve the conflict between the mass transfer and the reaction of protease in pelt might be to produce/employ smaller bating proteases.
\end{abstract}

Keywords: Bating, Protease, Mass transfer, Interfacial tension, Electrostatic interaction, Molecular weight

\section{Introduction}

Enzymes play a critical role in many biological and chemical processes due to their high efficiency and specificity as biocatalysts $[1,2]$. Protease is a most widely used enzyme in biomedical field [3, 4], food industry [5], detergent industry $[6,7]$, leather industry $[8]$, etc. The leather industry converts cattle hide, sheepskin or pigskin into artistic garment, shoe, glove, furniture and automotive upholstery leathers $[9,10]$. To produce soft and supple leather without loose grain, it is essential to fully remove unwanted non-collagenous proteins (such as albumin, globulin, elastin, proteoglycan, etc.) from the raw hide or skin (collagen network) [11], while the damage to collagen should be as little as possible. This purpose is usually achieved by "bating" pelt (unhaired hide/skin) with protease [12-14]. The use of commercial proteases like trypsin has already a century-old history in bating process [15]. However, until now, it has been prone to cause excessive damage to hide collagen,

\footnotetext{
* Correspondence: zengyunhang@scu.edu.cn

${ }^{1}$ National Engineering Laboratory for Clean Technology of Leather

Manufacture, Sichuan University, Chengdu 610065, China

Full list of author information is available at the end of the article
}

particularly the collagen in the grain, and thus decides the leather quality. This is because most proteases have the reaction/relative specificity rather than the structural/absolute specificity. They are specific for splitting peptide bonds of proteins rather than cleaving proteins. For example, trypsin is able to cleave the array of proteins including unwanted proteins in pelt and hide collagen into smaller peptide fragments, although it is specific for the sequences ...K।... or ...R $\mid$... (' $\mid$ ' = cleavage site) [16]. So it is very difficult for proteases to avoid hydrolyzing hide collagen during bating process. Moreover, the proteases with high efficiency of proteolysis transfer slow in pelt due to the thickness and the porous feature of the pelt $[17,18]$, so they stay longer on the pelt surfaces such as the grain and flesh surfaces than in the middle layer and result in more hydrolysis of collagen on the grain surface, which may damage the natural pattern of the grain surface and the aesthetic property of leather (see Fig. 1).

To reduce or eliminate the risk of excessive proteolysis of collagen during bating for obtaining high-quality leather, researchers have been committed to screen the protease that only hydrolyze non-collagenous proteins 


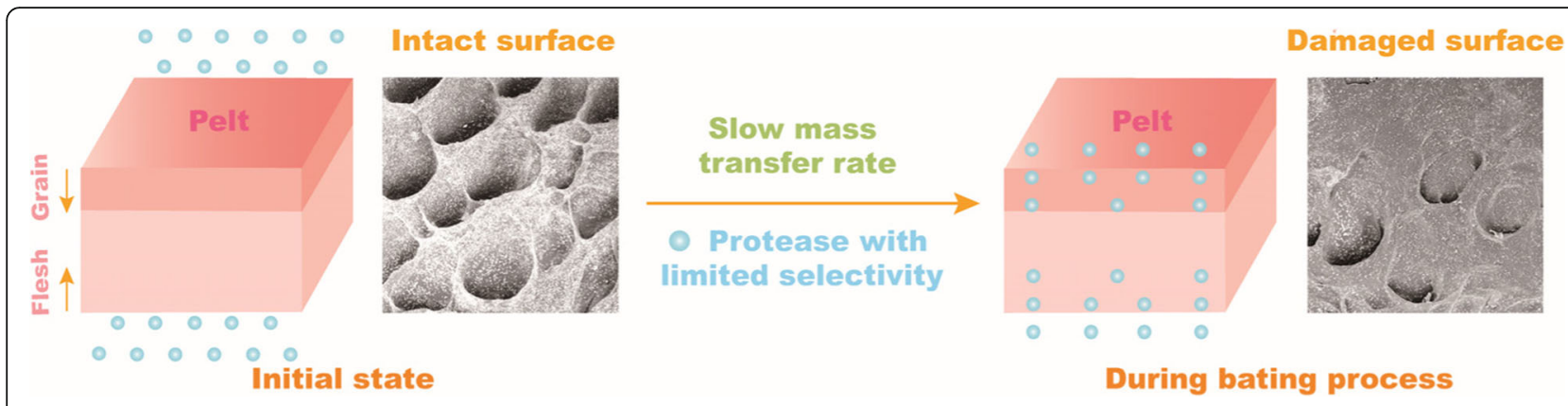

Fig. 1 Schematic diagram of protease transfer rate in pelt during bating. Higher concentration and longer retention time of protease in the surface layer than in the middle layer are prone to cause a dramatic damage to the natural pattern of the pelt surface

without cleaving collagen [19-22]. But in fact it is not easy to find this kind of highly specific protease. Since proteases transfer slow and react fast in pelt, the proteolysis of pelt during bating is mainly controlled by protease transfer rate in pelt. Undoubtedly, enhancement of the mass transfer rate of protease in pelt would reduce difference between its reaction time in the surface layers (grain and flesh layers) and that in the middle layer, which is an effective solution to excessive collagen proteolysis in the surface layers [23]. However, few studies have focused on enhancement of the protease transfer rate in pelt due to the lack of method for accurately locating protease in pelt. Recently, a useful method for visualizing and quantifying protease in pelt has been developed based on the fluorescent tracer technique [24, 25]. This method makes it possible to investigate the factors influencing protease transfer rate during bating process.

Tanners usually rationalize the bating process by adjusting protease dosage, using protease and auxiliaries together or choosing proteases from various microorganisms [20-22] to meet the requirement of bating performance. These are undertaken mostly by tanners' experience and lack of scientific guidance. Hence, a true understanding of how to obtain more efficient bating performance is theoretically and practically significant. In this study, effects of protease dosage, bating auxiliaries and molecular weight of protease on both protease transfer rate and collagen damage were investigated. The bating auxiliaries chosen herein were the most widely used ones such as penetrant JFC (fatty alcoholpolyoxyethylene ether [26]) and ammonium sulfate [14]. The distribution of protease in bated pelt was observed using the fluorescent tracer technique to analyze the protease transfer rate. The surface appearance of the bated pelt and the concentration of hydroxyproline in bating effluent were tested to evaluate the damage extent of collagen. The concentration of protein in bating effluent and the softness of crust leather were measured to assess the bating performance. Additionally, the factors affecting protease transfer rate in pelt were discussed from the viewpoints of concentration gradient, interfacial tension, electrostatic interaction and steric hindrance. The results obtained would be enlightening for enhancement of protease transfer rate and reduction in collagen damage during bating.

\section{Materials and methods}

\subsection{Materials}

Delimed pelts ( $2.4 \mathrm{~mm}$ in thickness) were prepared by treating cow hides with conventional procedures, as shown in Additional file 1: Table S1, and used for bating trials. Trypsin from bovine pancreas (biological reagent, $23 \mathrm{kDa}$, proteolytic activity $250,000 \mathrm{U} / \mathrm{g}$ at $30^{\circ} \mathrm{C}$ and $\mathrm{pH}$ 8.5 ) and bovine serum albumin (BSA, molecular biology grade, $66 \mathrm{kDa}$ ) were purchased from Shanghai Aladdin Biochemical Technology Co., Ltd. Albumin from chicken egg white (molecular biology grade, $44 \mathrm{kDa}$ ), fluorescein isothiocyanate isomer I (FITC, $\geq 90 \%$ (HPLC)), Sephadex G-25 (fine) were purchased from Sigma-Aldrich Co. LLC. Commercial penetrating agent JFC was purchased from Jiangsu Haian Petrochemical Plant (China). Ammonium sulfate (AS, analytical grade) was purchased from Chengdu Jinshan Chemical Reagent Co., Ltd. (China). All the chemicals used for leather processing were of commercial grade, and the chemicals used for analyses were of analytical grade.

\subsection{Effect of protease dosage on bating performance}

Three pieces of delimed pelts were bated with different dosages of proteases and $100 \%$ water (based on weight of delimed pelt) at $30{ }^{\circ} \mathrm{C}$ for $60 \mathrm{~min}$. The proteases used herein were $0.10 \%$ FITC-trypsin (fluorescent labeled trypsin prepared according to the method described in our previous study $[23,27]$, which retained $72 \%$ of relative proteolytic activity and had similar molecular weight to trypsin (Additional file 1: Table S2 and Figure S4)), $0.25 \%$ FITC-trypsin, and $0.50 \%$ protease mixture $(0.25 \%$ FITC-trypsin $+0.25 \%$ trypsin), respectively. It should be noted that, to obviously and easily detect the changes in mass transfer of protease in pelt and bating performance 
with increasing protease dosage, the proteolytic activity of trypsin was much higher than those of commercial bating agents because the pelts used for the bating trials were no more than $200 \mathrm{~g}$, and the used small-scale lab drum had much weaker mechanical action than the industrial drum used in large-scale leather manufacture. Moreover, the FITC-trypsin dosage was in the range of $0.10 \%-0.25 \%$ since the fluorescence intensity emitted under this dosage was suitable for observation of trypsin in pelt using fluorescence microscope.

After bating for $30 \mathrm{~min}$ and $60 \mathrm{~min}$, the pelts were sampled and cut into vertical sections of $20 \mu \mathrm{m}$ thickness on a freezing microtome (CM1950, Leica, Germany). The sections were observed using an inverted fluorescence microscope (Ti-U, Nikon, Japan) to locate FITC-trypsin in the pelts, and then the fluorescence micrographs were processed by Image J software to semi-quantify the relative content and the penetration rate of FITC-trypsin in the pelts. Specifically, a curve of brightness of each position occurred by FITC-trypsin vs. the distance between each position and grain surface was first drawn. The relative content of FITC-trypsin of each position and the penetration rate of FITC-trypsin in pelt were then calculated by Formulas (1) and (2), respectively:

$$
\% \text { relative content }=\frac{\text { brightness of each position }}{\text { maximum brightness in pelt }} \times 100
$$

\%penetration rate $=\frac{\text { thickness of pelt with brightness }}{\text { total pelt thickness }} \times 100$

Additionally, the surface morphology of the pelt samples was observed with scanning electron microscope (SEM, Phenom Pro, Phenom, China), and the effluent samples were collected for determination of the concentrations of total protein and hydroxyproline as reported in the documents $[28,29]$. The determined concentration of total protein means that the sum of non-collagenous protein concentration, collagen concentration and trypsin concentration. The hydroxyproline concentration is usually used to evaluate the concentration of collagen (hydrolyzed from pelts) because hydroxyproline is a main amino acid component in collagen rather than in other proteins. Furthermore, the difference between the concentration of total protein and that of hydroxyproline can show the removal of non-collagenous protein to some extent.

Furthermore, after bating for $60 \mathrm{~min}$, the bated three pelts were pickled, chrome-tanned, shaved, rewetted, neutralized, retanned, dyed, fatliquored and dried in vacuum according to the processes described in Additional file 1: Table S3. As a result, the crust leathers were obtained. After conditioning at $20^{\circ} \mathrm{C}$ and $65 \%$ relative humidity for $48 \mathrm{~h}$, the softness of the crust leathers was analyzed using a softness tester (GT-303, Gotech, Taiwan) [30].

\subsection{Effect of auxiliaries on bating performance of protease \\ 2.3.1 Analysis of bating performance of trypsin in the presence of auxiliaries}

To investigate the effects of common bating auxiliaries such as penetrant and ammonium salt on the mass transfer rate of protease in pelt, one piece of delimed pelt was bated with $0.1 \%$ FITC-trypsin and $100 \%$ water (based on weight of delimed pelt) at $30^{\circ} \mathrm{C}$ for $60 \mathrm{~min}$ as the control group, and another two pieces of delimed pelts were bated in the same conditions except addition of $0.5 \%$ JFC and $1.0 \%$ AS, respectively. After bating for $30 \mathrm{~min}$ and $60 \mathrm{~min}$, the pelt samples and the effluent samples were collected for observation of the FITCtrypsin in pelt and the surface appearance of pelt, and determination of the concentrations of total protein and hydroxyproline in effluent, respectively.

Moreover, after bating for $60 \mathrm{~min}$, the three bated pelts were treated as described in Section 2.2 to obtain crust leathers, and the softness of crust leathers was also measured.

\subsubsection{Analysis of properties of trypsin in the presence of auxiliaries}

To assay the effects of JFC and AS on the proteolytic activity of trypsin, a trypsin solution $(0.1 \mathrm{mg} / \mathrm{mL}, \mathrm{pH} 8.5)$, a solution $(\mathrm{pH} 8.5)$ containing $0.1 \mathrm{mg} / \mathrm{mL}$ trypsin and $0.5 \mathrm{mg} / \mathrm{mL}$ JFC and a solution ( $\mathrm{pH} 8.5)$ containing 0.1 $\mathrm{mg} / \mathrm{mL}$ trypsin and $1.0 \mathrm{mg} / \mathrm{mL}$ AS were prepared, respectively. The proteolysis was performed by mixing 1 $\mathrm{mL}$ of the enzyme solution with $1 \mathrm{~mL}$ of $2 \%(\mathrm{w} / \mathrm{v})$ casein solution ( $\mathrm{pH} \mathrm{8.5)}$ at $30^{\circ} \mathrm{C}$ for $10 \mathrm{~min}$ and then stopped by adding $2 \mathrm{~mL}$ of $0.4 \mathrm{~mol} / \mathrm{L}$ trichloroacetic acid. Subsequently, the amount of tyrosine in the mixture was measured with Folin-Ciocalteu reagent by the method described in the literature [31]. One unit of proteolytic activity was defined as the amount of protease that releases $1 \mu \mathrm{g}$ tyrosine per minute.

Moreover, the interfacial tension of a trypsin solution $(1.0 \mathrm{mg} / \mathrm{mL})$ and a solution containing $1.0 \mathrm{mg} /$ $\mathrm{mL}$ trypsin and $5.0 \mathrm{mg} / \mathrm{mL}$ JFC was measured using a contact angle goniometer (DSA30, Krüss, Germany). The zeta potentials of a trypsin solution $(1.0 \mathrm{mg} / \mathrm{mL})$ and a solution containing $1.0 \mathrm{mg} / \mathrm{mL}$ trypsin and 10.0 $\mathrm{mg} / \mathrm{mL}$ AS at $\mathrm{pH} 8.5$ were determined using a zeta potential \& particle size analyzer (Nano Brook Omni, Brookhaven, USA). 
2.4 Effect of molecular weight of protease on its transfer rate during bating

To investigate the effect of molecular weight of protease on its mass transfer rate in pelt, three protease or protease models, trypsin $(23 \mathrm{kDa})$, albumin $(44 \mathrm{kDa})$ and BSA $(66 \mathrm{kDa})$, were employed to treat three pieces of delimed pelts, respectively. This is because trypsin, albumin and BSA can be easily FITC-labeled and purified. In particular, it is difficult to accurately assess the effect of molecular weight of protease on its mass transfer in pelt as well as the bating performance by using proteases of different molecular weights due to their different hydrolysis of protein substrates including non-collagenous proteins and collagen.

The effective diameters of trypsin, albumin and BSA in aqueous solution were determined by zeta-potential \& particle size analyzer (see Additional file 1: Figure S1). The fluorescent labeled protease or models, FITCtrypsin, FITC-albumin and FITC-BSA, were prepared as described in our previous study [23, 24, 27], and they all had high purity (Additional file 1: Figure S2), high fluorescence intensity (Additional file 1: Figure S3) and molecular weight similar to trypsin, albumin and BSA, respectively (Additional file 1: Table S2 and Figure S4).

Additionally, the delimed pelt was treated with $0.5 \%$ protease or model (including 50\% FITC-labeled protease or model, w/w) and $100 \%$ water (based on weight of delimed pelt) at $30^{\circ} \mathrm{C}$ for $90 \mathrm{~min}$. After treating for 30 $\mathrm{min}, 60 \mathrm{~min}$ and $90 \mathrm{~min}$, the bated pelts were sampled to observe the distributions of the FITC-protease or FITCprotease model in pelt.

\section{Results and discussion}

\subsection{The effect of protease dosage on bating performance}

The concentration gradient is an important factor that affects the mass transfer rate of protease in pelt. The increase in protease dosage will undoubtedly enhance the protease transfer in pelt, viz., shorten the time for protease transfer from the grain or flesh layers to the middle layer. But protease could lead to excessive hydrolysis of hide proteins including non-collagenous proteins and collagen if its dosage is too much. Until now, the relation among protease dosage, protease transfer rate and bating performance remains theoretically unclear. In this section, the effect of protease dosage on the protease transfer rate during bating was investigated by observing the distribution of protease in bated pelts after bating with various dosages of trypsin, and that on the damage to pelt was evaluated by analyzing the surface morphology of bated pelts and the concentration of hydroxyproline in bating effluents. Additionally, the effect of protease dosage on the bating performance was assessed
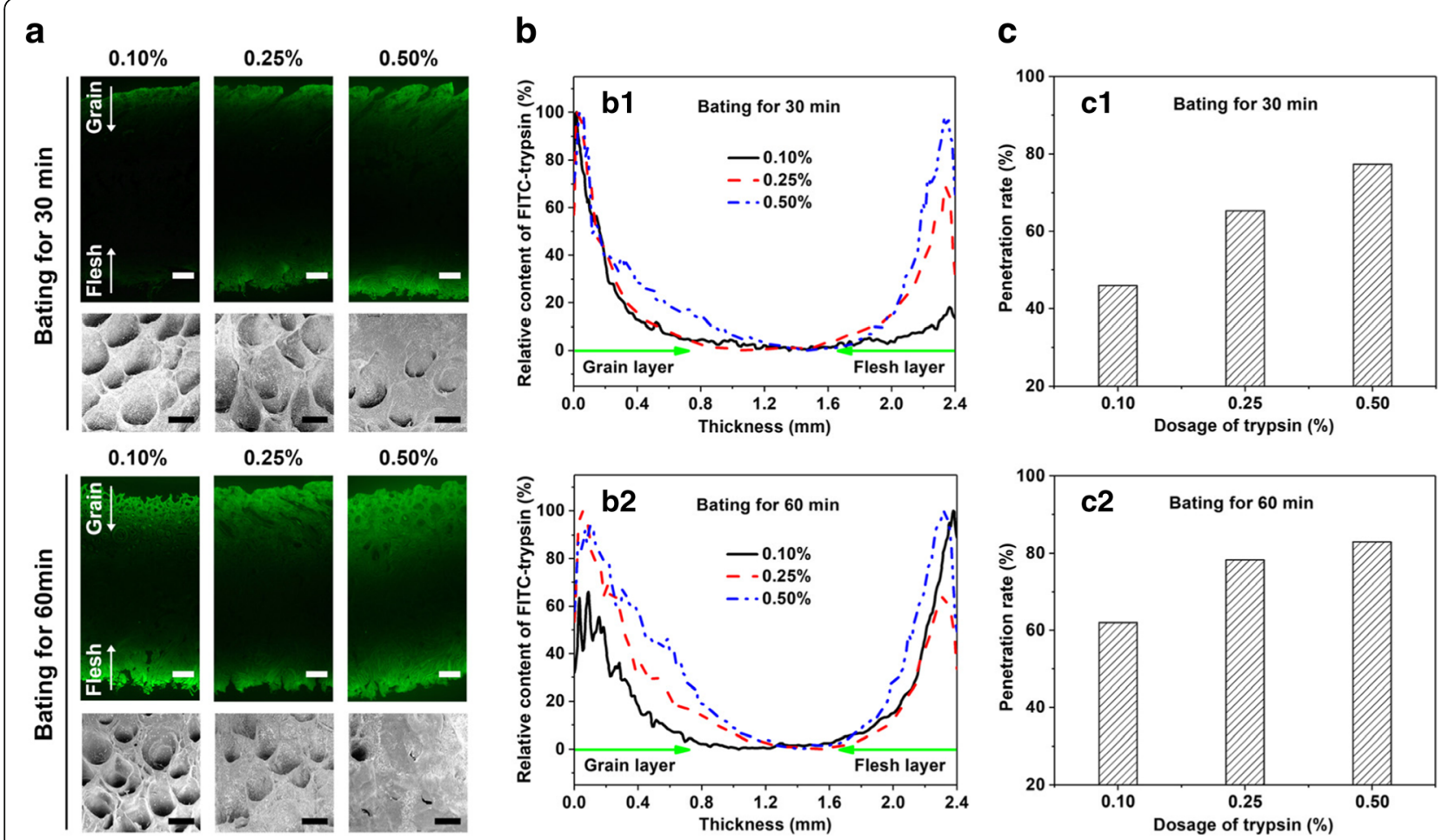

Fig. 2 (a) Fluorescence micrographs of vertical sections $(\mathrm{bar}=500 \mu \mathrm{m})$ and SEM micrographs of pelt surfaces $(\mathrm{bar}=200 \mu \mathrm{m})$ from the pelts bated with different dosages of trypsin and FITC-trypsin mixture for $30 \mathrm{~min}$ and $60 \mathrm{~min}$; (b) relative contents and (c) penetration rates of FITC-trypsin in the pelts bated for $30 \mathrm{~min}(\mathrm{~b} 1, \mathrm{cl})$ and $60 \mathrm{~min}(\mathrm{~b} 2, \mathrm{c} 2)$ obtained by analysis of (a) using Image J software 
by measuring the concentration of total protein in bating effluents and the softness of crust leathers after chrometanning and post-tanning the bated pelts with conventional procedures.

From Figs. 2a, b and c, it can be seen that the penetration depth, relative content and penetration rate of FITC-trypsin in pelt increase with increasing dosage of trypsin. However, increasing trypsin dosage by 5 -fold (from $0.10 \%$ to $0.50 \%$ ) only resulted in a less than 2 -fold increase in its penetration rate after bating for $30 \mathrm{~min}$ (Fig. 2c1). Moreover, even if bating with $0.50 \%$ trypsin for $60 \mathrm{~min}$, the penetration rate of FITC-trypsin in pelt was still below $85 \%$ (Fig. 2c2). Unfortunately, a dramatic damage to the natural pattern of pelt surface resulted from increasing dosage of trypsin (Fig. 2a). In particular, the natural pattern on the grain surface almost disappeared when using $0.5 \%$ trypsin, meaning that the bated pelt suffered serious damage.

As shown in Fig. 3a, the total protein concentration in bating effluents remarkably increased with increasing dosage of trypsin, which was mainly due to the addition of more trypsin and the removal of more proteins including non-collagenous proteins (such as albumin, globulin, elastin, proteoglycan, etc.) and collagen from pelt. Fig. 3b showed an increase in the hydroxyproline concentration of bating effluents (suggesting hydrolysis of more collagen) with increasing dosage of trypsin. Here, because the total protein concentration, the trypsin dosage and the hydroxyproline concentration all increased, it was difficult to determine whether the concentration of non-collagenous proteins increased. The data in Fig. 4 indicated that the softness of crust leather increased with increasing trypsin dosage. This should be mainly due to the removal of more proteins from pelt, especially the hydrolysis of more collagen. As for the limited difference in the leather softness, it should be because the softness of crust leather was a comprehensive index affected by bating, tanning and retanning processes. Higher trypsin dosage led to higher removal rates of proteins from pelt and contributed to production of softer leather, but it also probably brought about higher uptake of tanning and retanning agents, reducing the leather softness.

These results showed that the mass transfer rate of protease in pelt could be enhanced by using more protease but accompanied with greater damage to hide collagen and even damaged grain surface as well as loose grain. The more hydrolysis of hide collagen caused by increasing protease dosage dominates the unsatisfactory final bating performance even if the transfer rate of protease in pelt and the softness of crust leather can be improved. Thus, enhancement of protease transfer rate in pelt simply by increasing protease dosage is an impractical option because of greater collagen damage. Therefore, it's essential to adopt other approaches to enhance the protease transfer rate in pelt, which would not increase collagen damage.

\subsection{The effect of auxiliaries on bating performance}

In bating process, tanners usually use protease together with some auxiliaries such as penetrant [26] and ammonium salt [14] to improve bating performance. In this part, the protease transfer rate and the hydrolysis of hide proteins by using trypsin together with penetrating agent JFC or ammonium sulfate (AS) were compared with those by only using trypsin. Moreover, the changes in interfacial tension of trypsin solution and surface charge property of trypsin after adding JFC and AS were investigated, respectively, to explain why these auxiliaries benefit bating performance and to provide theoretical guidance for developing effective approach that can both enhance protease transfer in pelt and reduce damage to hide collagen.

After bating for $30 \mathrm{~min}$ and $60 \mathrm{~min}$, the visual distribution, the relative content and the penetration rate of FITC-trypsin in pelts were shown in Figs. 5a, b and c, respectively. It was obvious that the penetration depths of FITC-trypsin in pelts were in the sequence of trypsin bated pelt $<$ trypsin-JFC bated pelt $<$ trypsin-AS bated pelt. Specifically, it just took less than 30 min for trypsin
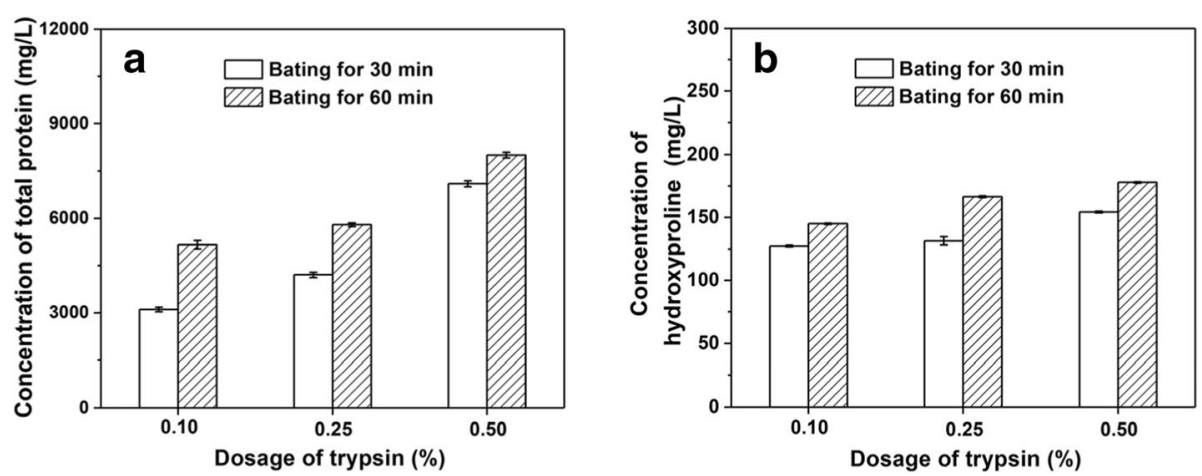

Fig. 3 Effects of trypsin dosage on concentrations of total protein (a) and hydroxyproline (b) in bating effluents 


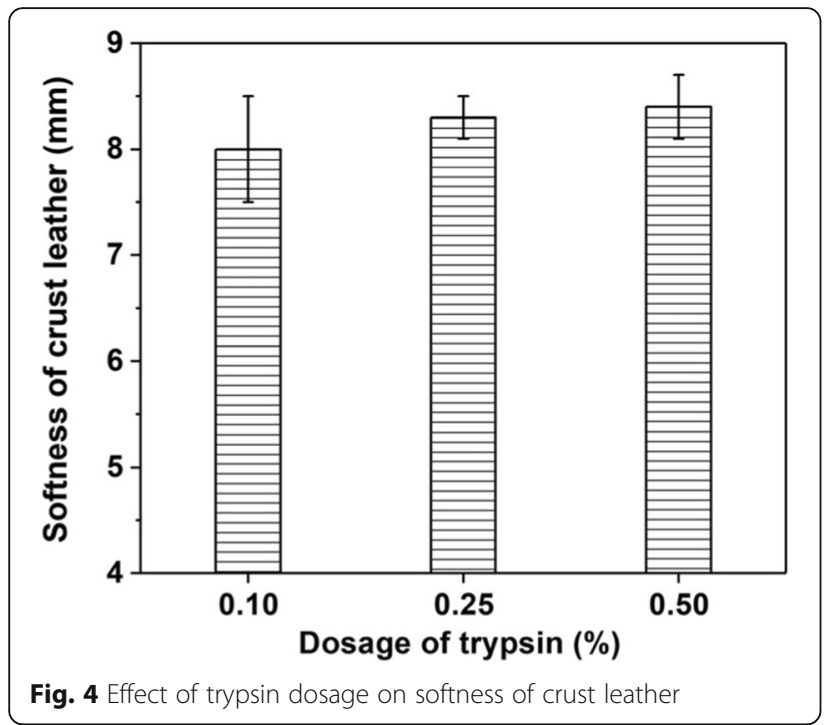

to penetrate the whole pelt when using $0.1 \%$ trypsin together with $1 \%$ AS. JFC was not as effective as AS, but the penetration rate of trypsin in pelt (about $70 \%$ ) by using $0.1 \%$ trypsin and $0.5 \%$ JFC was still much higher than the control (about 51\%) after bating for $30 \mathrm{~min}$. More interestingly, bating with trypsin and JFC or AS together kept the integrity of natural pattern on the pelt surface (see the SEM micrographs of the pelt surfaces in Fig. 5a), and generated higher total protein concentration (Fig. 6a) and less hydroxyproline concentration in bating effluents (Fig. 6b). These results meant that the addition of JFC and AS in bating process brought about the removal of more non-collagenous proteins (due to the same dosage of trypsin) with less collagen damage, which had obvious advantage compared with the increase in trypsin dosage from $0.1 \%$ to $0.5 \%$ that caused more damage to grain surface and hide collagen (Figs. 2a and $3 \mathrm{~b}$ ). This is mainly because the use of JFC or AS had a positive influence on the proteolytic activity of trypsin (Fig. 7a), and thus enhanced the proteolysis of non-collagenous proteins from the pelt. Meanwhile, the use of JFC decreased the interfacial tension of trypsin solution (Fig. 7b) and might increase the solubility and stability of trypsin in solution, which improved the wettability of trypsin solution and promoted the penetration of trypsin into pelt [32, 33], so that the transfer rate of trypsin in pelt was enhanced. As for the use of AS, the zeta potential data in Fig. 7c indicated that the negative charges of trypsin were dramatically increased at $\mathrm{pH} 8.5$ (the bating $\mathrm{pH}$ ) by adding AS because the surface of trypsin, a amphoteric protein macromolecule [34], could selectively adsorb $\mathrm{SO}_{4}{ }^{2-}$ of AS (the $\mathrm{NH}_{4}{ }^{+}$of AS mainly existed as $\mathrm{NH}_{3} \cdot \mathrm{H}_{2} \mathrm{O}$ at $\mathrm{pH}$ 8.5). This was helpful in

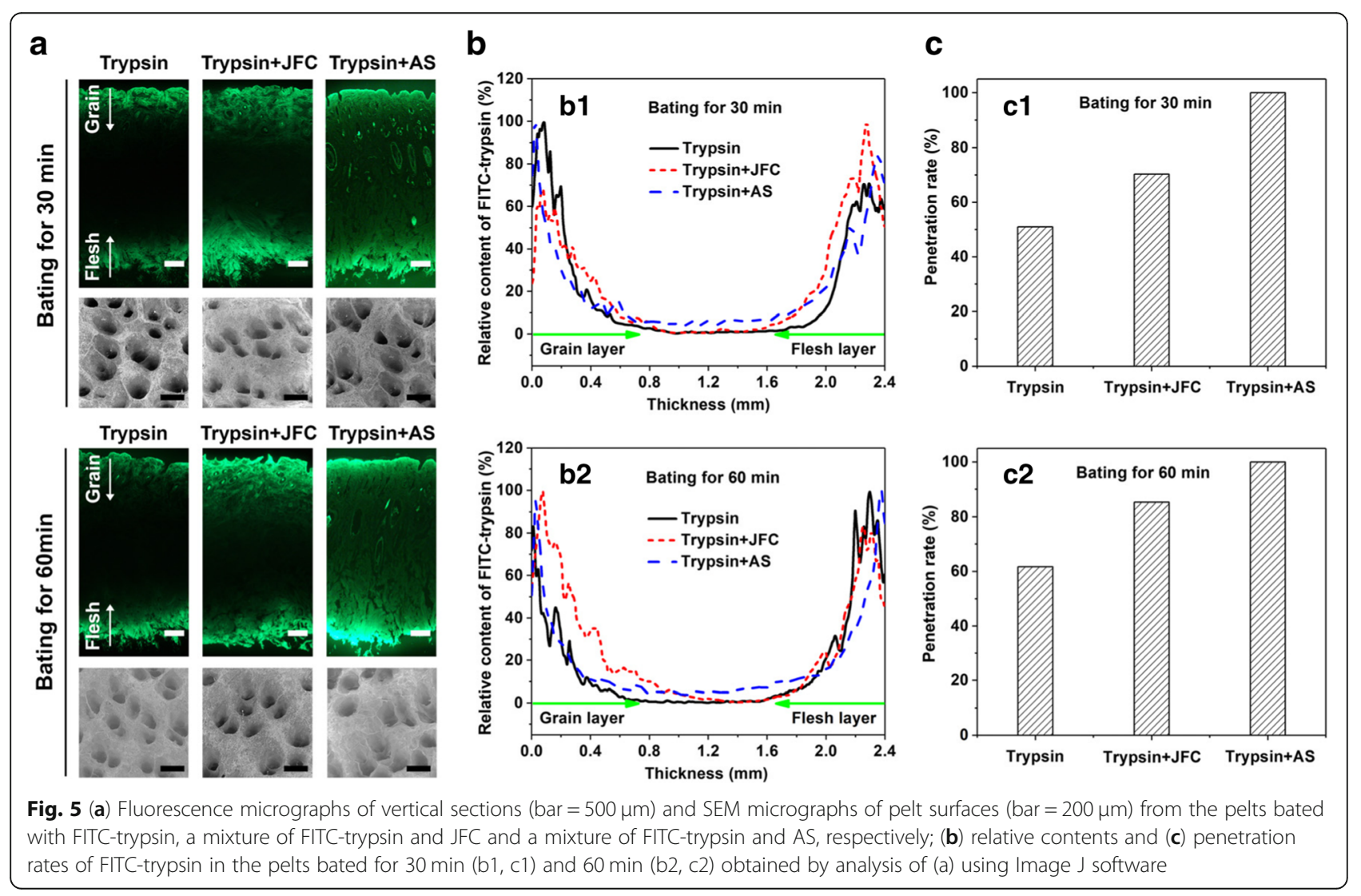



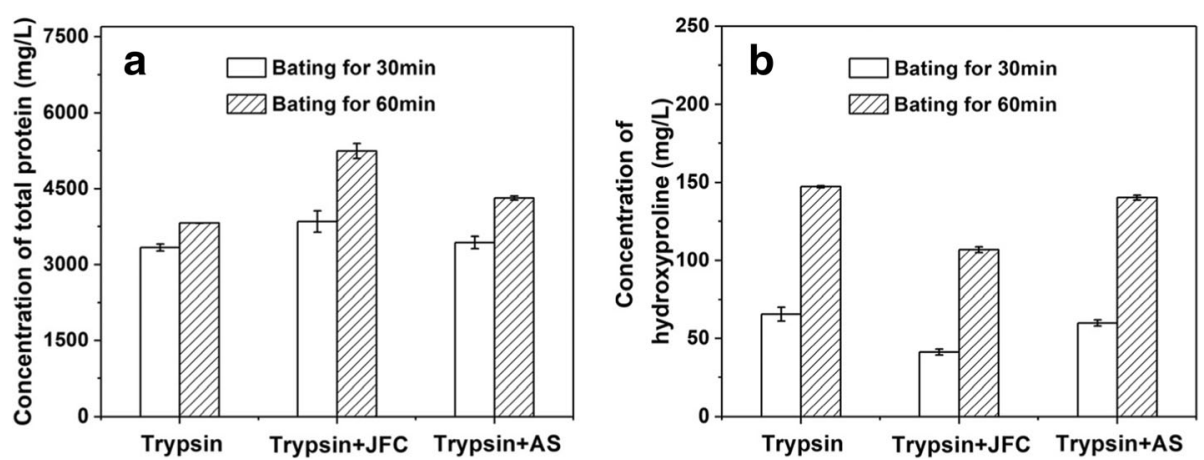

Fig. 6 Effects of JFC and AS on concentrations of total protein (a) and hydroxyproline (b) in bating effluents

reducing the electrostatic attraction between trypsin and the surface layer of pelt (pI 7.0, with negative charge) during bating and promoting the penetration of trypsin in pelt. The faster mass transfer rate of trypsin reduced the difference between its reaction time in the surface layers (grain and flesh layers) and that in the middle layer, so as to largely decrease collagen damage to pelt surface, especially grain surface.

Moreover, Fig. 8 showed that the crust leathers prepared with the trypsin-JFC bated pelt and the trypsin-AS bated pelt were not softer than that prepared with the trypsin bated pelt. There should be two reasons why the crust leathers bated with trypsin and JFC or AS were not softer. First of all, less hydrolysis of collagen was obtained by adding JFC or AS in bating (Fig. 6b) and therefore prevented leather from becoming empty or lacking fullness. Second, after bating with trypsin and JFC or AS together, higher removal rates of unwanted proteins from pelt (Fig. 6) as well as greater dispersion of hide collagen network were achieved, bringing about higher uptake of retanning agents and a better filling effect.

On the whole, compared with increasing protease dosage, decreasing interfacial tension and electrostatic attraction between protease and pelt is more effective in enhancement of protease transfer in pelt and reduction in excessive damage to collagen.

\subsection{The effect of molecular weight of protease on its mass transfer rate during bating}

Tanners and researchers all recognize that the molecular weight of protease affects its mass transfer rate in pelt [35]. However, few studies have directly reported the relationship between the molecular weight of protease and its mass transfer rate during bating because it is too difficult to accurately locate protease in pelt before. We chose high purity trypsin $(23 \mathrm{kDa}$, diameter $3.8 \mathrm{~nm})$, albumin $(44 \mathrm{kDa}$, diameter $5.9 \mathrm{~nm})$ and BSA $(66 \mathrm{kDa}$, diameter $8.9 \mathrm{~nm}$ ) as protease models to investigate the effect of molecular weight of protease on its mass transfer rate in pelt by using fluorescent tracer technique.

After treating pelts with $0.5 \%$ trypsin and FITC-trypsin mixture, $0.5 \%$ albumin and FITC-albumin mixture and 0.5\% BSA and FITC-BSA mixture separately, the visual distributions of FITC-trypsin, FITC-albumin and FITCBSA (green) in the pelts were obtained, as shown in Figs. 9a1, a2 and a3, respectively. These fluorescence micrographs indicated that a lower molecular weight of protease led to a sharper increase in the penetration depth of protease with increasing time. After treating for $90 \mathrm{~min}$, the penetration depths of FITC-trypsin, FITCalbumin and FITC-BSA in the grain layers were 1.39 $\mathrm{mm}, 0.75 \mathrm{~mm}$ and $0.28 \mathrm{~mm}$, respectively, and those in the flesh layers were $0.54 \mathrm{~mm}, 0.45 \mathrm{~mm}$ and $0.50 \mathrm{~mm}$,
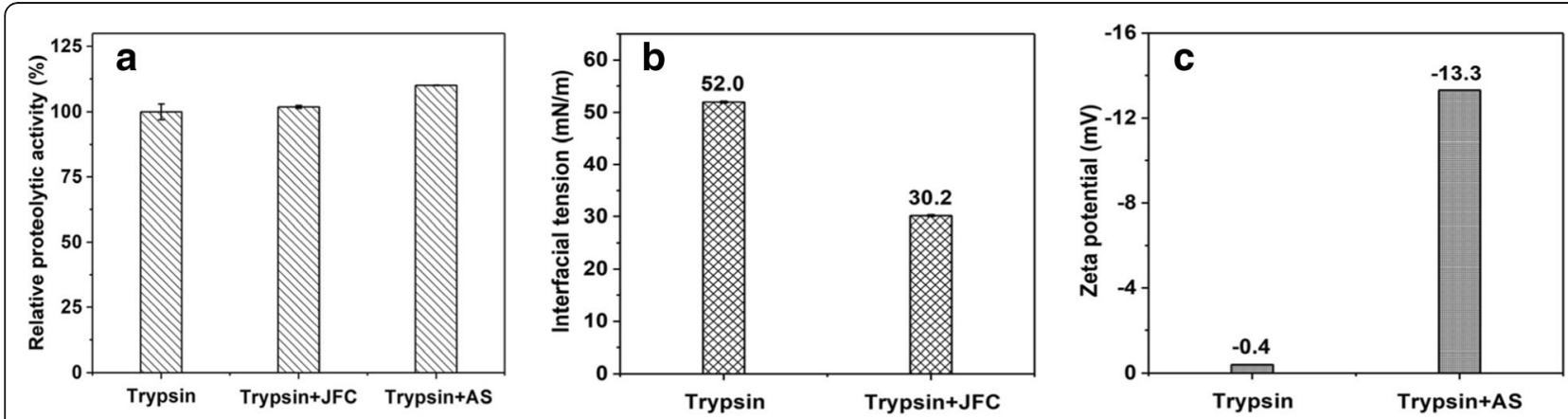

Fig. 7 (a) Effects of JFC and AS on proteolytic activity of trypsin; (b) effect of JFC on interfacial tension of trypsin solution; (c) effect of AS on zeta potential of trypsin 


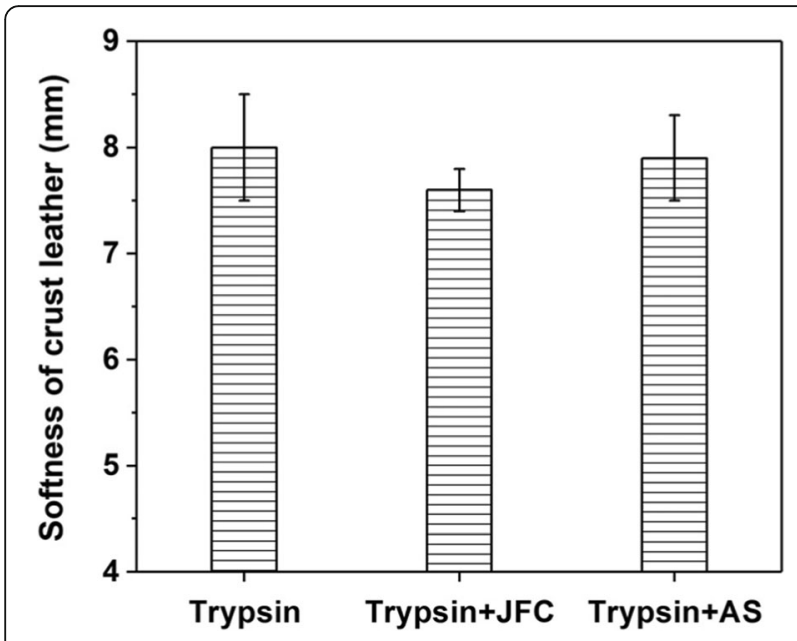

Fig. 8 Effect of JFC and AS on softness of crust leather

respectively (see Fig. 9b1). The penetration rates of FITC-trypsin, FITC-albumin and FITC-BSA in the pelts were about $86 \%, 50 \%$ and 32\%, respectively (Fig. 9b2). This is mainly because their diameters were in the sequence of trypsin < albumin < BSA, and trypsin with lower molecular weight and steric hindrance transferred faster in pelt. These results suggest that employment of proteases with lower molecular weight is beneficial to enhancement of protease transfer rate in bating process. This is accordant with the former researches that the trypsin from pancreas works better than other proteases from microorganisms owing to its lower molecular weight $[36,37]$ and moderate proteolytic activity [14]. Therefore, to improve the bating performance, besides screening proteases with high specificity in hydrolyzing non-collagenous proteins, a possible direction would be to develop proteases which possess proper proteolytic activity and have a molecular weight as low as possible.

\section{Conclusions}

Increasing protease dosage is not a desirable approach to enhance its mass transfer rate in pelt because it would cause greater damage to grain surface and hide collagen. Interfacial tension, surface charge property and molecular weight of protease are important factors affecting protease transfer rate in bating process. Decreasing interfacial tension of protease solution by using proper surfactants and increasing surface negative charge of protease can effectively improve the mass transfer rate of protease in pelt while reducing collagen damage,
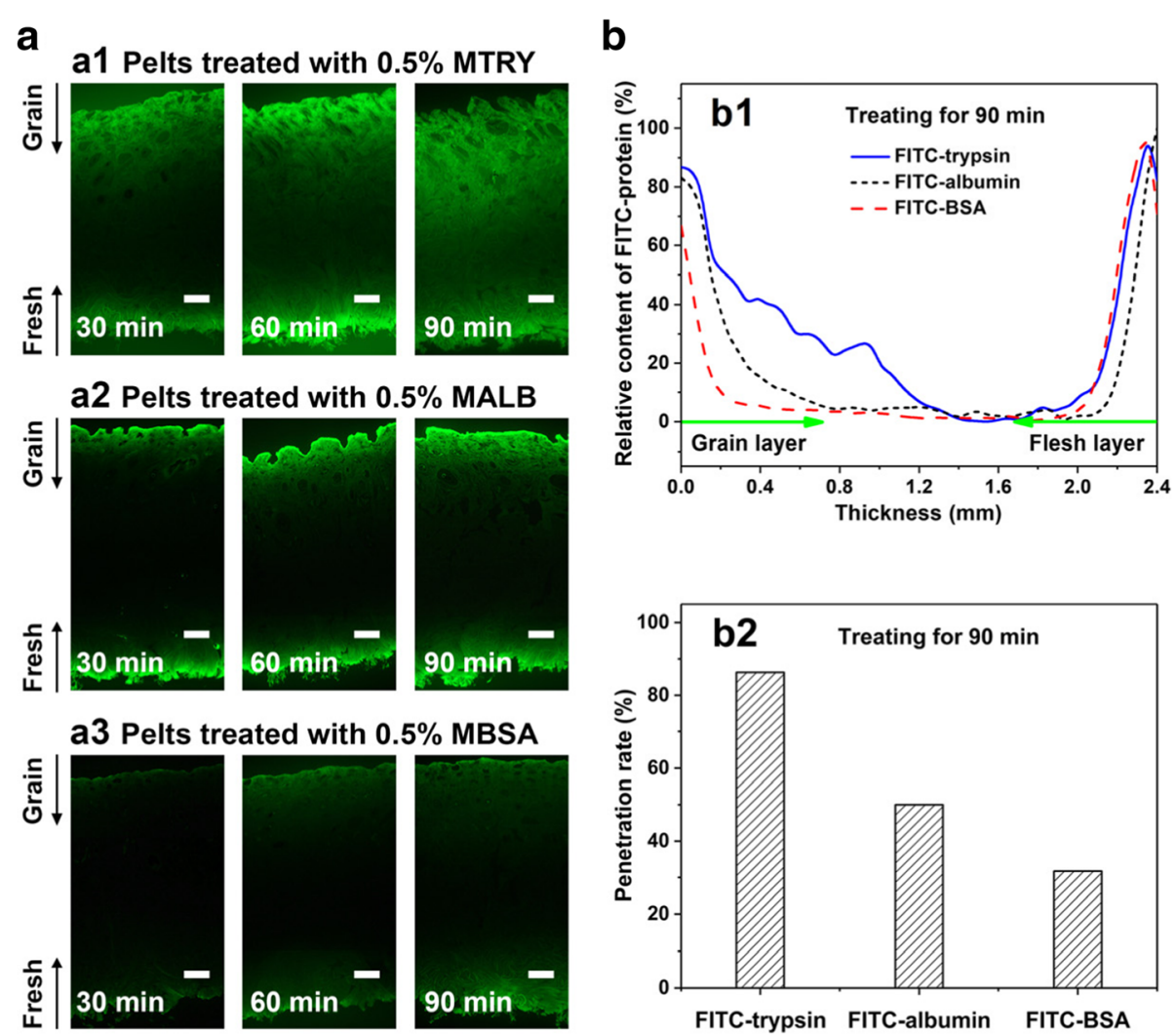

Fig. 9 (a) Fluorescence micrographs of vertical sections from pelts (bar = $500 \mu \mathrm{m})$ treated with the mixture of trypsin and FITC-trypsin (MTRY) (a1), the mixture of albumin and FITC-albumin (MALB) (a2) and the mixture of BSA and FITC-BSA (MBSA) (a3); (b) relative contents (b1) and penetration rates (b2) of FITC-trypsin, FITC-albumin and FITC-BSA in the pelts treated for 90 min (obtained by analysis of (a) using Image J software) 
which is beneficial to the production of high-quality leather with intact natural pattern. This research also implies that the lower molecular weight of proteases is positively related to their bating performance. Therefore, the development of low molecular weight proteases with satisfactory enzyme activity would be a potential approach to improve bating process.

\section{Additional file}

Additional file 1: Figure S1. Distributions of particle sizes of trypsin (a), albumin (b) and BSA (c) in aqueous solutions (1 $\mathrm{mg} / \mathrm{mL})$. Figure $\mathbf{S 2}$. Chromatograms of FITC-trypsin (a), FITC-albumin (b) and FITC-BSA (c) on a Sephadex G-25 gel-filtration column $(3.5 \mathrm{~cm} \times 85 \mathrm{~cm})$. The column was eluted with ultrapure water at a flow rate of $1.0 \mathrm{~mL} / \mathrm{min}$, and the absorbance of the eluate was measured at $495 \mathrm{~nm}$ (the absorbance maximum of FITC) using an ultraviolet-visible spectrophotometer. Figure S3. Fluorescence emission spectra of FITC, protease/proteins and FITC-labeled protease/proteins obtained using an excitation wavelength of $495 \mathrm{~nm}$ (the excitation maximum of FITC).

Figure S4. SDS-PAGE of protease/proteins and FITC-labeled protease/proteins with different molecular weights. $\mathrm{M}=$ marker; $1=\mathrm{BSA} ; 2=$ FITC-BSA; $3=$ albumin; 4 = FITC-albumin; 5 = trypsin; 6 = FITC-trypsin. Table S1. Conventional procedures for preparing delimed pelt from salted cow hide. Table $\mathbf{S 2}$. FITC/protein molar ratio (F/P). Table S3. Conventional procedures for preparing crust leather from bated pelt. (DOCX $2960 \mathrm{~kb}$ )

\section{Abbreviations}

AS: Ammonium sulfate; BSA: Bovine serum albumin; FITC: Fluorescein isothiocyanate isomer I; JFC: Commercial penetrating agent (fatty alcoholpolyoxyethylene ether); SEM: Scanning electron microscope

\section{Acknowledgements}

Not applicable

\section{Authors' contributions}

YS performed the experiments about the effect of auxiliaries on bating performance and was a major contributor in data analyses and writing the manuscript. SW performed and interpreted the experiments regarding the effects of protease dosage and auxiliaries on leather softness. QY performed the experiments about the effects of dosage and molecular weight of protease on bating performance. HL performed the experiment about the effect of JFC on protease transfer. YZ was a major contributor in the conception of the study, the discussion of the results and the revision of the manuscript. BS performed the revision of the manuscript. All authors read and approved the final manuscript.

\section{Authors' information}

Not applicable

\section{Funding}

This work was supported by the National Natural Science Foundation of China $(21878193,21406145)$, the Innovation Team Program of Science \& Technology Department of Sichuan Province (2017TD0010), the Graduate Student's Research and Innovation Fund of Sichuan University (2018YJSY086) and the National Innovation and Entrepreneurship Training Program for Undergraduate (201810610140).

\section{Availability of data and materials}

All data needed to evaluate the conclusions in the paper are present in the paper and the supplementary material.

\section{Competing interests}

The authors declare that they have no competing interests.

\section{Author details}

${ }^{1}$ National Engineering Laboratory for Clean Technology of Leather Manufacture, Sichuan University, Chengdu 610065, China. ${ }^{2}$ Key Laboratory of
Leather Chemistry and Engineering (Sichuan University), Ministry of Education, Chengdu 610065, China.

Received: 14 May 2019 Accepted: 24 June 2019

Published online: 29 July 2019

\section{References}

1. Bornscheuer UT, Huisman GW, Kazlauskas RJ, Lutz S, Moore JC, Robins K. Engineering the third wave of biocatalysis. Nature. 2012;485:185-94.

2. Jegannathan $\mathrm{KR}$, Nielsen PH. Environmental assessment of enzyme use in industrial production-a literature review. J Clean Prod. 2013;42:228-40.

3. Abidi F, Chobert J-M, Haertlé T, Marzouki MN. Purification and biochemical characterization of stable alkaline protease Prot-2 from Botrytis cinerea. Process Biochem. 2011;46:2301-10.

4. Qin X, Khuong AC, Yu Z, Du W, Decatur J, Gross RA. Simplifying alternating peptide synthesis by protease-catalyzed dipeptide oligomerization. Chem Commun. 2012:49:385-7.

5. Bernal C, Guzman F, Illanes A, Wilson L. Selective and eco-friendly synthesis of lipoaminoacid-based surfactants for food, using immobilized lipase and protease biocatalysts. Food Chem. 2018;239:189-95.

6. Da Silva OS, De Almeida EM, De Melo AHF, Porto TS. Purification and characterization of a novel extracellular serine-protease with collagenolytic activity from Aspergillus tamarii URM4634. Int J Biol Macromol. 2018;117: 1081-8

7. Zhang H, Li H, Lang DA, Xu H, Zhu H. Purification, characterization and potential applications of a novel halotolerant metalloprotease from marine bacterium Vibrio sp. LA-05. J Chem Technol Biotechnol. 2018;93:3627-37.

8. Foroughi F, Keshavarz T, Evans CS. Specificities of proteases for use in leather manufacture. J Chem Technol Biotechnol. 2006;81:257-61.

9. Dixit S, Yadav A, Dwivedi PD, Das M. Toxic hazards of leather industry and technologies to combat threat: a review. J Clean Prod. 2015;87:39-49.

10. Dettmer A, Ayub MAZ, Gutterres M. Hide unhairing and characterization of commercial enzymes used in leather manufacture. Braz J Chem Eng. 2011; 28:373-80.

11. Schropfer $\mathrm{M}$, Klurer $\mathrm{E}$, Meyer $\mathrm{M}$. Influence of elastin degradation on the mechanical properties of leather. J Amer Leather Chem Ass. 2014;109:306-13.

12. Sizeland KH, Edmonds RL, Basil-Jones MM, Kirby N, Hawley A, Mudie S, et al. Changes to collagen structure during leather processing. J Agric Food Chem. 2015;63:2499-505.

13. Jaouadi NZ, Rekik H, Elhoul MB, Rahem FZ, Hila CG, Aicha HSB, et al. A novel keratinase from Bacillus tequilensis strain Q7 with promising potential for the leather bating process. Int J Biol Macromol. 2015;79:952-64.

14. Wang YN, Zeng YH, Liao XP, Zhang WH, Shi B. Removal of calcium from pelt during bating process: an effective approach for non-ammonia bating. J Amer Leather Chem Ass. 2013;108:120-7.

15. Monsheimer R, Pfleiderer E. Enzymatic bating method. US Patent. 1976; 06/ $104,832$.

16. Renicke C, Spadaccini $R$, Taxis C. A tobacco etch virus protease with increased substrate tolerance at the P1' position. PLoS One. 2013;8:e67915.

17. Fathima NN, Kumar MP, Rao JR, Nair BU. A DSC investigation on the changes in pore structure of skin during leather processing. Thermochim Acta. 2010:501:98-102.

18. Sivakumar V, Jena A, Gupta K, Mandal AB. Analysis of pore-size related parameters for the leather matrix through capillary flow porosimetry technique. J Soc Leather Technol Chem. 2015;99:16-22.

19. Dettmer A, Coelho Cavalheiro J, Cavalli É, Misturini Rossi D, De Souza Gusatti C, Záchia Ayub MA, et al. Optimization of the biotechnologica process for hide unhairing in substitution of toxic sulfides. Chem Eng Technol. 2012:35:803-10

20. Ganesh Kumar A, Swarnalatha S, Sairam B, Sekaran G. Production of alkaline protease by Pseudomonas aeruginosa using proteinaceous solid waste generated from leather manufacturing industries. Bioresour Technol. 2008; 99:1939-44.

21. Sundararajan S, Kannan CN, Chittibabu S. Alkaline protease from Bacillus cereus VITSN04: potential application as a dehairing agent. J Biosci Bioeng 2011:111:128-33.

22. Friedrich J, Kern S. Hydrolysis of native proteins by keratinolytic protease of Doratomyces microspores. J Mol Catal B Enzym. 2003;21:35-7.

23. Yang $Q$, Zeng $Y H$, Zhang WH, Liao XP, Shi B. Investigation of mass transfer characteristics of protease in bating process using fluorescence tracing. China Leather. 2015;44:16-9. 
24. Yang Q, Zeng YH, Zhang WH, Liao XP, Shi B. Research on mass transfer and action mechanism of enzymes in leather processing by fluorescence tracing (I): establishment of tracer technique based on BSA. China Leather. 2014;43:19-22.

25. Ma JZ, Hou XY, Gao DG, Lv B, Zhang J. Greener approach to efficient leather soaking process: role of enzymes and their synergistic effect. J Clean Prod. 2014;78:226-32

26. Li YH, Luo FX, Peng BY, Xu BB. Impact of typical surfactants on the collagenolytic and elastinolytic activities of proteases. J Amer Leather Chem Ass. 2015;110:227-36.

27. Zeng YH, Yang Q, Wang YN, Zhou JF, Shi B. Neutral protease assisted lowsulfide hair-save unhairing based on pH-sensitivity of enzyme. J Amer Leather Chem Ass. 2016;111:345-53.

28. Lowry OH, Rosebrough NJ, Farr AL, Randall RJ. Protein measurement with the folin phenol reagent. J Biol Chem. 1951;193:265-75.

29. Reddy GK, Enwemeka CS. A simplified method for the analysis of hydroxyproline in biological tissues. Clin Biochem. 1996;29:225-9.

30. IUP 36. Measurement of leather softness. J Soc Leather Technol Chem. 2000; 84:377-9.

31. Zeng $Y H$, Kong X, Wang YN, Liao XP, Zhang WH, Shi B. Effective component in alpha-amylase preparation for unhairing. J Amer Leather Chem Ass. 2013; 108:86-93.

32. Chaudhari SP, Dugar RP. Application of surfactants in solid dispersion technology for improving solubility of poorly water soluble drugs. J Drug Deliv Sci Tec. 2017:41:68-77.

33. Kumar S, Mandal A. Studies on interfacial behavior and wettability change phenomena by ionic and nonionic surfactants in presence of alkalis and salt for enhanced oil recovery. Appl Surf Sci. 2016;372:42-51.

34. Yang C, Zhou XL, Liu YR, Wang J, Tian LL, Zhang Y, et al. Charged groups synergically enhance protein imprinting in amphoteric polyacrylamide cryogels. J Appl Polym Sci. 2016;133:43851.

35. Song Y, Ma Y, Zeng YH, Shi B. Effect of molecular weight of protease on its mass transfer in leather processing. Leather Sci Eng. 2018;28:5-10.

36. Zambare $V$, Nilegaonkar S, Kanekar P. A novel extracellular protease from Pseudomonas aeruginosa MCM B-327: enzyme production and its partial characterization. New Biotechnol. 2011;28:173-81.

37. Sumathi C, Mohanapriya D, Mandal AB, Sekaran G. Production of different proteases from fish gut microflora utilizing tannery fleshing. Eng Life Sci. 2012;12:223-37.

\section{Publisher's Note}

Springer Nature remains neutral with regard to jurisdictional claims in published maps and institutional affiliations.

\section{Submit your manuscript to a SpringerOpen ${ }^{\circ}$ journal and benefit from:}

- Convenient online submission

- Rigorous peer review

- Open access: articles freely available online

- High visibility within the field

- Retaining the copyright to your article

Submit your next manuscript at $\boldsymbol{\nabla}$ springeropen.com 